Submission ID: 14330

\title{
The Effect of Owner Birth Order on R\&D Investments in Family Firms
}

\begin{abstract}
The debate on whether family firms are risk-averse or risk-taking in $R \& D$ activities is yet inconclusive. Move beyond prior studies assuming family influence as a whole, this study aims to investigate the impact of a nascent but essential factor, family owner's early life experience which is largely captured by their birth orders, on R\&D investment decisions. Drawn on evolutionary theory related to birth order effect and family innovation literature, we conceptualize that birth order of family owners will affect how they perceive the preservation of socioemotional endowment and react to risk-taking strategy, namely $R \& D$ investment in this study. We propose that later-born family owners tend to be risk-takers and invest more in $R \& D$ projects compared with those who are earlier-borns. However, the proposed enduring birth order effect will also be hindered or promoted in the family firms where family management also sets boundaries. We further expect that the positive association between birth order and R\&D investments is weakened and strengthened respectively when a family member is the chairperson on the board and when there is a presence of owner-CEO duality. We confirm our hypotheses by using a sample of 747 firm-year observations from Chinese listed family firms during the period of 2006-2014. The results confirm the role of "family" life in understanding of innovation heterogeneities among family firms, and we believe it also serves as a strong case to cross-pollinate ideas among family business, innovation strategy and family science which is much-needed in management and strategy area.
\end{abstract}

\section{Keywords:}

Birth order; family firms; R\&D investment; evolutionary psychology; CEO duality 
"Family firms are affected by both the imprinting of the family and firm and environmental pressures for conformity and change."

---(Sharma, Chrisman, Chua, \& Steier, 2019: 11)

Firms are keen to engage in research and development (R\&D) activities as it is recognized as an essential way to develop technological capabilities, create and sustain competitive advantages (e.g., Block, 2012; De Massis, Frattini, \& Lichtenthaler, 2013; McDermott \& O'Connor, 2002). However, it is debatable and complex when it comes to explain innovation activities among family firms, a unique organization form that are constantly making decisions in a deep intertwining of economic goals and non-economic goals, or so called the endowment of "socioemotional wealth (SEW)" (e.g., Block, 2012; Chrisman, Chua, De Massis, Frattini, \& Wright, 2015; Chrisman \& Patel, 2012; Gomez-Mejia, Cruz, Berrone, \& De Castro, 2011; Gomez -Mejia, Haynes, Núñez-Nickel, Jacobson, \& Moyano-Fuentes, 2007). Evidently, prior studies have inconclusive findings regarding how family firms behave in $R \& D$ investments. Some studies find that family firms tend to be risk-averse and underinvest in R\&D given the mounting risks and uncertainties associated with R\&D investments threatening their SEW (Block, 2012; Chen \& Hsu, 2009; De Massis et al., 2013; Matzler, Veider, Hautz, \& Stadler, 2015; Munari, Oriani, \& Sobrero, 2010; Muñoz-Bullón \& Sanchez-Bueno, 2011; Schmid, Achleitner, Ampenberger, \& Kaserer, 2014). However, another stream proposes a contingent view and argues that whether R\&D investments are risk-averse or risk-taking depends on how family firms interpret R\&D investments against SEW under a certain context, such as performance gap or growth opportunities (Choi, Zahra, Yoshikawa, \& Han, 2015; Chrisman \& Patel, 2012), firm slack (Liu, Chen, \& Wang, 2017), governance structure (Chen \& Hsu, 2009; Duran, Kammerlander, Van Essen, \& Zellweger, 2016; Sciascia, Nordqvist, Mazzola, \& De Massis, 
2015), and generations stages (Duran et al., 2016; Kraiczy, Hack, \& Kellermanns, 2015; Schmid et al., 2014).

Regardless the divergent views among prior studies, it predominantly highlights that family ownership and family management as a whole are the center of understanding family firms' R\&D strategies. Surprisingly, given the importance of family influence on R\&D investments, we have limited knowledge about how the family owner, especially their early life experience in a family, influences their decision-making on R\&D investments. Such downplaying would hinder our understanding of heterogeneous R\&D behaviors among family firms because, on the one hand, family owner is the important individual, who ultimately owns and may also manage the company (Gomez-Mejia et al., 2011). Their life experience may shape who they are and hence may exercise substantial influence on firms' strategies, such as R\&D investments (Chrisman \& Patel, 2012; Gomez-Mejia et al., 2011). On the other hand, compared with non-family firms, the distinct nature of family firms essentially arises from the "family', "the most and enduring of all human social groupings" (Smith, Hamon, Ingoldsby, \& Miller, 2012: 5), and where family owner grows and develops values and beliefs of interpreting and responding external environment (Gomez-Mejia et al., 2011; Sulloway, 1995). In this regard, family owners' early life experience within the family would have persistent and enduring impact on their predispositions toward risks and their strategic decisions in the later life (Campbell, Jeong, \& Graffin, 2019; Sulloway \& Zweigenhaft, 2010). To fill the gap, this study extends existing literature by purposively focusing on family owner's birth order, which largely captures the early life experience of an individual within a family environment (Sulloway, 1999), and its impact on family firms' R\&D investments. 
Birth order, or the "relative rank of a child in terms of the age hierarchy among siblings in the family," (Steelman, 1985: 354) has been of great interest to the public and evolutionary psychology scholars (e.g., Booth \& Kee, 2009; Steelman, 1985; Sulloway, 1995). Various studies suggest that birth order is one of the most influential factors capturing individual's early-life within a family domain and predicting various individual behaviors (Jaskiewicz, Combs, Shanine, \& Kacmar, 2017; Sulloway, 1995, 1996a, 2001). Importantly, few organizational studies have started to link birth order to leadership succession and its performance in family firms (Calabrò, Minichilli, Amore, \& Brogi, 2018; Kimhi, 1997; Schenkel, Yoo, \& Kim, 2016). This implicitly highlights that, if we understand the birth order effects on family firms' strategic behaviors, we could have a comprehensive understanding of family firms' strategy and performance heterogeneities once the successor is decided based on birth order (Calabrò et al., 2018). Building on evolutionary psychology, SEW perspective and innovation literature, we thus attempt to shift focus of family ownership and management as a whole to the individual's early life experience within a family domain by developing theory to explain how family owners' birth order influences their interpretations of R\&D investments using SEW as a frame of reference.

Drawn on Darwin's theory of natural selection (Darwin, 1968), a key finding from evolutionary psychology theory is that siblings are biologically driven to compete with each other for parental investments or fulfill "family niches" (Sulloway, 1995, 1999, 2001). To garner parental favor, siblings tend to differentiate themselves in an effort to minimize direct competition (Darwin, 1968; Hamilton, 1964; Trivers, 1974). Evidently, siblings' strategies vary with birth order because birth order "causes siblings to experience family relationship in dissimilar ways and to pure different ways of maximizing their parent's investments" Sulloway (1999: 190). As a result of birth order, individuals will develop different dispositions and 
tendencies that will have enduring and persistent impact on how they make decisions in the adulthood (Sulloway, 1995, 1996b). Relevantly, birth order studies have noted that birth order can have significant impact on individuals' risk-taking behaviors (e.g., Bertoni \& Brunello, 2016; Gilliam \& Chatterjee, 2011; Sulloway, 1994; Sulloway \& Zweigenhaft, 2010). Building on this logic, we conceptualize that birth order shapes family owner's tolerance of risks, which, in turn, will affect their interpretation of $\mathrm{R} \& \mathrm{D}$ investments against SEW. Parents invest more in earlier-borns children which makes earlier-born siblings are endowed with heavier familial roles and tend to identify more closely with parents and authority (Sulloway, 2001; Sulloway \& Zweigenhaft, 2010). For this reason, earlier-borns are more conforming, conventional and defensive which make them family protecters and conservative decision makers. In contrast, later-born siblings tend to have less parental investments which make them usually differentiate themselves through engaging in risk-taking activities for currying parent favor (Campbell, Jeong, \& Graffin, 2018; Saad, Gill, \& Nataraajan, 2005; Sulloway, 1996b, 2001; Sulloway \& Zweigenhaft, 2010). As SEW is a primary frame of reference of decision-making in family firms (Berrone, Cruz, \& Gomez-Mejia, 2012; Gomez-Mejia et al., 2011; Gomez-Mejia et al., 2007), we expect that earlier-born siblings tend to label $R \& D$ as a threat to SEW while later-born siblings are more tolerated with risks and less concerned with SEW. Therefore, we propose that the ascending birth order of family owners may be related to higher R\&D investment in family firms.

Family ownership alone cannot make strategic decisions into full execution (Sirmon, Arregle, Hitt, \& Webb, 2008). Indeed, R\&D investments decisions should be a joint interactions between family owner and family members' managerial presence in the organization, namely family management (Chua, Chrisman, \& Sharma, 1999; Sirmon et al., 2008). Therefore, we 
further contend that the enduring birth order impact on R\&D investments is contingent on two important but contrasting conditions. First, family owner may sense high level of concern on SEW from other family members on board (Matzler et al., 2015), especially when the family member is the chairperson. Second, family owners could also enjoy superior managerial discretion in decision-makings when they are also the CEO in the company, so called owner-CEO duality (Duran et al., 2016). We expect that family member as chairperson may hinder the positive impact of birth order on $R \& D$ investment because family owners' concerns on preserving SEW becomes salient. In contrast, when owners are also CEOs in the company, their risk-tolerances are significantly manifested because of increased discretion for making decisions and allocating resources for strategy implementation (Baliga, Moyer, \& Rao, 1996; Kim, Kim, \& Lee, 2008). Hence, we expect a stronger effect of birth order on R\&D investment under the presence of owner-CEO duality.

We collected 747 firm-year observations of Chinese family listed firms from 2006 to 2014 and found full empirical support for our theoretical predictions. Our study makes three primary contributions. First, given the inconclusive debate on family firms' R\&D investments, we introduce a nascent but remarkable factor, the birth order of family owners in explaining heterogeneities among family firms' R\&D behaviors. Our conceptualization of family owners' birth order shifts from the focus on family ownership and family management that has implicitly treated the family influence as a whole. Instead, built on evolutionary psychology theory, we find that family influence significantly varies with family owners' characteristics, especially their early life experience (i.e., birth order). Our study reveals a new way to solve family influence-innovation debate by considering variances at the individual level. The significant moderating effects of the presence of family member as chairperson and owner-CEO duality 
strengthen our conceptualization of birth order effects and highlight the contrasting governance factors in shaping family owners' risk-tolerances toward R\&D investments. These further echoes the recent call for exploring heterogeneities among family firms for better understanding family firms' behaviors rather than simply comparing family firms with non-family firms and assuming family firms are homogenous as a group (Chua, Chrisman, Steier, \& Rau, 2012). Our integration of evolutionary psychology and family business also contributes to the promising stream calling for incorporating evolutionary psychology to resolve empirical debates in family business studies (Nicholson, 2008a; Yu, Stanley, Li, Eddleston, \& Kellermanns, 2019). Second, by adding "family" life into family business research, we can better explain why variances of individuals lead to various managerial decisions in the family business studies, highlighting familial factors as part of the organizational landscape (Dyer, 2003; Jaskiewicz et al., 2017). Third, we also advance context-sensitive SEW which suggest that SEW is not constant but varies with different contexts (Berrone et al., 2012; Chrisman et al., 2015; Minichilli, Nordqvist, Corbetta, \& Amore, 2014).

\section{THEORY AND HYPOTHESES DEVELOPMENT}

\section{Birth Order Effects in Evolutionary Psychology}

Birth order studies have their strongest momentum in evolutionary psychology (Schooler, 1972; Sulloway, 1995). Darwin (1968)'s nature selction theory provides the theoretical foundations for evolution psychology by suggesting that human beings adapt to their environment over time. During the adaptation process, especially in a family, sibling-sibling conflicts (or sibling rivalry) are one of the basic principal in the evolutionary process (Darwin, 1968; Hamilton, 1964; Trivers, 1974). That is, siblings are biologically driven to compete for 
maximizing parental investments. In doing so, children must strategize for safeguarding access to parental resources and stake out a unique "family niche" to increase survival success (Darwin, 1859; Dunn \& Plomin, 1990; Hamilton, 1964; Sulloway, 1995; Trivers, 1974). Even “parents normally encourage equal sharing among their offspring, offspring will generally prefer to acquire more of any scarce resource than they give to a sibling", (Sulloway, 1996a: 60). Such sibling rivalry can be observed throughout species including humans and sometimes ends in an extreme, infanticide, a phenomenon that is widespread among insects, fish, birds, and mammals (Sulloway, 1996a).

Since parental attention and resources are unevenly distributed, siblings develop different strategies to maximize parental favor. This is why birth order plays a role in behaviors because birth order "causes siblings to experience family relationship in dissimilar ways and to pure different ways of maximizing their parent's investments" Sulloway (1999: 190). In other words, birth order differences across individuals arise "as a result of how children are raised (functional birth order, or rearing order) rather than the sequence in which they are born (Sulloway, 1999: 189). As a result of birth order, individuals will develop different dispositions and tendencies toward external environment and approaches to respond (Sulloway, 1995, 1996b). Evidently, a vast number of studies have linked birth order to individual's personality traits (e.g., Hertwig, Davis, \& Sulloway, 2002; Sulloway, 1996a). Building on these, a growing number of research has particularly investigated birth order effects on risk-taking behaviors (Sulloway, 1995, 1996a, 2001; Sulloway \& Zweigenhaft, 2010), such as participation in risky sports (Sulloway \& Zweigenhaft, 2010), risky adolescent behaviors (Argys, Rees, Averett, \& Witoonchart, 2006), and financial investments (Gilliam \& Chatterjee, 2011). 
Given birth order capturing individual's early family life, it is surprising that family business research has not more fully embraced of it. Only a few exceptions that linked birth order to leadership succession in family firms (Nicholson, 2008a, b). In terms of leadership succession, studies find that choosing the eldest son to be successor is more likely when there is a high level of SEW endowment because he/she may maximize family continuity (Barnes, 1988; Calabrò et al., 2018; Schenkel et al., 2016). In this study, we incorporate insights from evolutionary psychology on birth order effects and argue that birth order shapes family owner's interpretation of R\&D investments using SEW as a frame of reference offering a novel explanation of heterogeneities on $R \& D$ investments across family firms.

\section{SEW Logic and R\&D Investments}

Socioemotional wealth (SEW), which is defined as the "non-financial aspects of the firm that meet the family's needs, such as identity, the ability to exercise family influence, and the perpetuation of the family dynasty" (Gomez-Mejia et al., 2007: 106), is undoubtedly the unique nature of family firms compared with other organizational forms (Gomez-Mejia et al., 2011). According to SEW logic, it suggests that family firms strive to preserve and enhance the family's SEW, which includes nonfinancial aspects or "affective endowments," apart from economic considerations (Berrone et al., 2012; Gomez-Mejia et al., 2011; Gomez-Mejia et al., 2007). The SEW logic offers a theoretically grounded explanation of behaviors observed in family firms such as succession (Minichilli et al., 2014), risk-taking (Gomez-Mejia et al., 2007), diversification (Gomez-Mejia, Makri, \& Kintana, 2010), and CSR (Berrone, Cruz, Gomez-Mejia, \& Larraza-Kintana, 2010) (See detailed reviews from Gomez-Mejia et al. (2011) and Berrone et al. (2012)). It is implicitly assumed in the existing family business studies that SEW is "a key 
criterion, or at least one that has a greater priority, is whether their socioemotional endowment will be preserved" (Gomez-Mejia et al., 2007:11). In other words, SEW gains or losses are a critical frame of reference for decision making (Berrone et al., 2012). Similarly, this is also the case when investigating family firms' engagement in R\&D investments (Gomez-Mejia et al., 2011).

Most literature finds that family firms tend to be conservative in $R \& D$ investments (Chrisman \& Patel, 2012; Duran et al., 2016; Muñoz-Bullón \& Sanchez-Bueno, 2011) (For a comprehensive review, see De Massis et al. (2013)). Considering the preservation of SEW, family members' altruism (i.e., the tendency to undertake actions that help family heirs) and wealth control orientation will evoke risk-aversion and underinvestment in R\&D (Duran et al., 2016; Schulze, Lubatkin, \& Dino, 2003). These are consistent with Wiseman and Gomez-Mejia (1998) who suggests that family firms will be more risk-averse when they feel that they may lose a great deal of wealth. On contrary, some studies also find that family firms embrace risky decisions due to family firms' long-term perspective and nature alignment interests between owners and managers, thereby mitigating principal-agent problems (Ashwin, Krishnan, \& George, 2015). However, some other studies take a contingent view and suggest that risk-taking or risk-averse depends on the framing of R\&D in a certain context. For example, Chrisman and Patel (2012) find that family firms tend to engage more in $R \& D$ investments than nonfamily firms when the gap between aspirations and performance is negative. Gomez-Mejia et al. (2014) find that the increasing institutional investor ownership weakens the negative relationship between family ownership and R\&D investments because the presence of institutional owners make family firms more sensitive to the necessity of gains from $R \& D$ and negative effects of underinvestment. 
Other studies also find that resources slack (Liu et al., 2017), governance structure (Chen \& Hsu, 2009; Duran et al., 2016; Sciascia et al., 2015), and generations stages (Duran et al., 2016; Kraiczy et al., 2015; Schmid et al., 2014) shapes family firms’ view of R\&D against SEW.

\section{Family owner birth order and R\&D investment}

R\&D investments are assumed to be pivotal for firms' competitive advantages. Family firms are no exception. However, R\&D projects are significantly long-term, highly uncertain, sunk-cost investments (Chen \& Hsu, 2009; Chrisman et al., 2015; Lee \& O'neill, 2003) with no fixed timeline or even certainty for payoffs (Chrisman \& Patel, 2012; Munari et al., 2010). For these reasons, $R \& D$ projects requires significant level of risks tolerance from decision-makers in the organization. Such tolerance of risks may vary with birth order.

Building on the evolutionary psychology and family innovation literature, we thus relate family owner birth order to R\&D investments because birth order influences the extent to which individuals may engage in risk-taking behaviors to deal with sibling competition for recalibrating parental investments. This tendency to engage in risky behaviors in the childhood should have profound and engrained influence on how they respond to external environment in their adulthood (Sulloway, 2001). For this reason, we argue that earlier-borns are more likely to interpret R\&D investments as a threat to SEW than later-borns.

In comparison with younger siblings, earlier-borns normally receive more family attention and care, are endowed with more familial responsibilities and expected to work for the continuation of the family (Campbell et al., 2019; Saad et al., 2005; Sulloway, 1996a). For example, earlier-borns have initial favored status in the sibling hierarchy and will be more like their parents, more adherent to principles, more conservative and cautious (Paulhus, Trapnell, \& Chen, 1999; Saroglou \& Fiasse, 2003; Sulloway, 1995, 1996a), and inherently should not be 
“taking unnecessary chances". For example, Gilliam and Chatterjee (2011) find that earlier-borns shows significantly less risk tolerance than later-born individuals. Instead, earlier-borns are expected to inherit and manage the family firm acting a role of family nurturers and protectors (Calabrò et al., 2018). Consequently, when deciding on R\&D investments, they tend to adhere to SEW logic and avoid risk for the sake of protecting the familial wealth. In addition, because of their already privileged family position, they would be foolhardy to invest substantially in $R \& D$ projects and risk losing much family wealth, especially if they lack the needed skills and would might lose their status if they share control with nonfamily investors (Chrisman et al., 2015; McDermott \& O'Connor, 2002; Sulloway, 1995).

In contrast, later-born siblings tend to have less-established roles in the family which drives them to compete with the established status of their older siblings (Sulloway, 1999). Studies have noted that to garner parents' resources and attention, later-borns normally find unique ways to distinguish themselves, perhaps by challenging parental authority and supporting "radical" revolutions (Sulloway, 1995, 1996a; Zweigenhaft \& Von Ammon, 2000). Through persistent differentiating practices in the past, they tend to be rebellious, innovative, revolutionary and risk-taking (Healey \& Ellis, 2007; Schenkel et al., 2016; Sulloway, 1996a; Zweigenhaft \& Von Ammon, 2000). For example, using a meta-analysis, Sulloway and Zweigenhaft (2010) find that laterborns are more likely to participate in risky sports. Bertoni and Brunello (2016) note that although earlier-born can have better wage in the beginning because of higher education, later-borns enjoy higher wage growth because of their higher propensity to take risks, such as changing jobs more frequently than later-borns. Following this, we expect laterborns tend to tolerate more risks and label R\&D as less threatening to SEW. 
In summary, since birth orders tend to cause significantly different tolerations of risks, earlier-born owners may be more likely to discourage highly risky R\&D investments to preserve SEW endowments, while later-born owners may be more active R\&D investors, leading us to propose:

Hypothesis 1: Ceteris paribus, the ascending birth order of the family owner is positively associated with R\&D investments in family firms.

\section{Hindering Risk-Taking: Family Member as the Chairperson on the Board}

Boards of directors question, advise and monitor important decisions including $R \& D$ investments within the company. When the focal owner's family member is the chairperson on the board, the family owner must frequently interact with the family member on firm's strategic issues, which, in turn, will have compelling impact on family owner's preferences in decision making (Miller, Le Breton-Miller, \& Lester, 2011). In family firms, family members' demands to ensure continuity and control of family business which call forth among family officers to be family nurturers and prioritize preserving SEW in decision-makings (König, Kammerlander, \& Enders, 2013; Munari et al., 2010). As such, the presence of a family member in the chairperson position actually represents and reinforce the importance of preserving SEW. Particularly in R\&D investment context which is high-risk and objectionable, the family chairperson will be very concerned about any risk-taking behaviors proposed by family owner and thus have strong incentive to ensure a proper preservation of SEW in the family. In addressing these demands, although later-borns tend to be R\&D risk-takers and believe the risk will pay off in the end, they will be discouraged to do so because it is potentially against family firms' favored strategy (conservation), and family member in the chairperson position will express pressures to the focal family owner. Even R\&D projects are promising, given its high potential loss to SEW, family 
member in the chairperson position will consistently remind and question the focal owner's decisions, requiring them to put substantial effort in persuading them from both economic and non-economic perspective (Gomez-Mejia et al., 2014; Gomez-Mejia et al., 2007). Therefore, for earlier-borns, they enjoy risk-adverse alignment with their family member. However, for risk-tolerate later-borns, they tend to be more concerned of preserving SEW, which in turn, suppress their risk-taking preferences and hinder investments in R\&D.

In contrast, when the chairperson is not from the family, risk-taking later-born owners will be less aware of SEW and found it easier to persuade board members to invest in long-term and promising R\&D projects particularly from an economic perspective. Taken together, we anticipate that the positive birth order effect on $R \& D$ investments is weakened when there is a presence of a family member as the chairperson on the board:

Hypothesis 2: Ceteris paribus, ascending birth order of the family owner will have a weaker positive relationship with $R \& D$ investments when a family member is the chairperson on the board.

\section{Promoting Risk-Taking: Family Owner-CEO Duality}

Considering that birth order affects tolerances to take risks, we also expect that the impact of birth order on R\&D investment is contingent on family firms' ability to realize and implement risky decisions; that is, whether they have enough managerial discretion to direct and allocate resources to support risk-taking strategies and buffer R\&D investment shocks (Chrisman et al., 2015; De Massis, Kotlar, Chua, \& Chrisman, 2014).

When family owners are also company CEOs, their powerful positions grant them higher discretion to pursue opportunities that might be counter to both economically rational investment decisions and SEW (Gomez-Mejia, Nunez-Nickel, \& Gutierrez, 2001; König et al., 2013). On the 
one hand, later-born owners can save much effort in pursuing their risk-taking ambitions without constantly being questioned by the board (Schmid et al., 2014). Instead, they benefit from the nature alignment between owners and managers which provides an effective leadership to the firm and reduces the confusions inside and outside stakeholders (Ashwin et al., 2015; Baliga et al., 1996). On the other hand, the owner-manager also has stronger incentives to monitor the management of firm assets (Block, 2012). To make sure the success of R\&D investment, later-born owners can use their high discretion to allocate sufficient resources to support their decisions and be highly confident of innovation output (Zahra, 2005). For these reasons, they will have stronger preferences for risk-taking R\&D. In contrast, when later-born owners are not CEOs, they may face excessive pressures and monitoring from the board given the mounting risks associated with R\&D investments (Duran et al., 2016; Gomez-Mejia et al., 2007), which will evoke enhanced agency costs for seeking support and restrictions on the latitude of managerial actions and decisions. Consequently, tendencies to undertake substantial R\&D investment will be hindered. We therefore propose,

Hypothesis 3: Ceteris paribus, ascending birth order of the family owner has a stronger positive relationship with $R \& D$ investments when the family owner is also the CEO.

\section{METHODOLOGY}

\section{Sample and Data}

We obtained the original sample of all family firms listed on the Shanghai or Shenzhen Stock Exchange of China between 2006 and 2014 from China Stock Market and Accounting Research (CSMAR) database. Although there are variations in the definition of family business, a general agreement is that family owners are in the position to exercise decisive power on key 
governance choices and strategies of the firm (Chua et al., 1999; Duran et al., 2016). Following this, we operationalized family firms as firms in which the ultimate owner is a family member or a family. Some studies proposed a minimum of 5 percent of the shares in the study (e.g., Peng \& Jiang, 2010). In order to ensure that family group holds substantial portion of voting stock, we followed Chrisman and Patel (2012), Gomez-Mejia et al. (2010) and La Porta, Lopez-de-Silanes, and Shleifer (1999), and used $10 \%{ }^{1}$ control rights share in the company as a cut-off. We took 2006 as the initial sample year because in 2006 China issued new accounting standards that required listed companies to disclose $\mathrm{R} \& \mathrm{D}$ investment information in their annual reports. As China government announced a change in the existing one-child policy to two-child policy in 2015, we limited our sample to the period of 2003 and 2014 to avoid external policy influences on our results. As such, during the period 2006 to 2014, our sample is under the period of one-child policy.

To test our hypotheses, we need detailed family background information such as birth order and the number of siblings. We used the full name of the ultimate family owner from the CSMAR database and manually collected family information from (a) all the prospectus and annual reports of sample firms as China Securities Regulatory Commission requires public firms to disclose detailed personal information of the chairperson as well as his or her relatives who engage in family firm management in the prospectus (Yu et al., 2019); (2) Internet: we used search engine such as Baidu (i.e., largest search engine in China) and Google to search sibling information in any public sources such as corporate official websites, specialized press articles, and books (e.g., corporate books or documentaries); 3) social networks such as LinkedIn. To

\footnotetext{
${ }^{1}$ For sensitivity test, we also used $20 \%$ and $30 \%$ as a cutoff point. The details will be discussed in the Robust Tests section.
} 
make sure accuracy and consistency of the sibling information, we cross-checked the above different sources. As there is no compulsory rules of disclosing detailed family information for family firms in China and the sensitive nature of the data, similar as other studies (e.g., Calabrò et al., 2018; Campbell et al., 2019), it should be noted that there are significant challenges in collecting sibling information for all family firms. For this reason, the potential biases may arise from some family firms that their family information is not publicly available. Therefore, we will adopt Heckman two-stage model to correct for such concerns and will be discussed in the Estimation method section. In addition, as our focus in the study is the birth order effect of the family owner, we strictly excluded firms whose family owner is from an only-child family as there is no birth order effect in this case (Campbell et al., 2019).

We also drew data regarding institutional development from the marketization index of the National Economic Research Institute (NERI) (Fan, Wang, \& Zhu, 2011). Firm basic information (e.g., industry, establish year, and headquarter location), accounting information (e.g., sales, assets, debt and ROA) and corporate governance data (e.g., board information and family ownership) were collected from the CSMAR database. After excluding heavily regulated financial firms, ST firms that faced high delisting risk, firms that issued debt exceeding asset value, cross-listed firms that faced different regulation environments, or firms with missing data, our final sample included 747 firm-year observations of 188 family listed firms between 2006 and 2014. We took one-year time lag between independent and control variables, and the dependent variables to mitigate endogeneity concerns.

\section{Measures}

Dependent variable. Following the widely-established measures in previous studies (e.g., Chrisman \& Patel, 2012; Gomez-Mejia et al., 2014; Greve, 2003; Kim et al., 2008), we measured 
$R \& D$ intensity as the percentage of $\mathrm{R} \& \mathrm{D}$ expenditure over total sales. This measure captures a firm's commitment to innovation which is well suited with our framework (Gomez-Mejia et al., 2014; Lee \& O'neill, 2003). It also allows us to compare R\&D investments between companies in the analyses (Chen \& Hsu, 2009).

Independent variable. Our independent variable is denoted as owner birth order. Following Campbell et al. (2018), we adopted an ordinal measure for owner birth order. It took the value of 1 for the firstborn owner, 2 for a second-born, 3 for a third-born etc. Alternatively, we also developed a birth order ratio by considering the size of owner's family in the Robust Tests section (Booth \& Kee, 2009).

Moderating variables. The first moderator indicates whether the chairperson is from owner's family. We developed a dummy variable, Family member chairperson, which equals to one if any family members except the focal owner is in the chairperson position and zero otherwise. Following Chrisman and Patel (2012), we defined family member as a person related by blood or by marriage to the owning family. The second moderating variable for testing Hypothesis 3 is the Owner-CEO duality. We developed an indicator variable that equals one if the family owner also serves as the CEO in the focal firm, and zero otherwise (Zahra, 2005).

Control variables. Aligned with studies regarding the determinants of corporate $R \& D$ investment, we included three sets of control variables that may systematically impact family firms' R\&D activities. We firstly controlled for family-level variables in our model. We controlled for the number of siblings as family size shapes parents' resources allocated to the owner which may confound with our birth order effect (Booth \& Kee, 2009; Campbell et al., 2019). We measured The number of siblings as the total count of siblings of the focal family owner. We also controlled for Family ownership, measured as the proportion of equity held by 
family members in the focal firm. Family ownership has been a long-lasting and factor in influencing family firms' innovation strategies (Beck, Janssens, Debruyne, \& Lommelen, 2011; Chrisman \& Patel, 2012). The first generation's decision making generally rests with the founder who is centralized in decision making while it may change over time as succeeding generation join the family firm management (Beck et al., 2011; Kraiczy, Hack, \& Kellermanns, 2014). We controlled for Generation, an indicator variable, which equals one if any later generation family member serves as one of top managers except for the founder, and zero otherwise. At the firm level, we accounted for Firm age measured as the number of years since foundation (Beck et al., 2011). Older firms are expected to be more conservative in risk-taking strategies. We controlled for firm size (measured by the natural logarithm of the firm's number of employees) as it affect firms affect resource endowment for R\&D investments (Gomez-Mejia et al., 2014; Sciascia et al., 2015). Aligned with prior literature (Chrisman \& Patel, 2012; Gomez-Mejia et al., 2014; Greve, 2003), we measured Financial slack as the ratio of current assets to current liabilities. Firms with high levels of financial slack have more resources available for risk-taking innovation strategies. R\&D investments also needs immediate cash to support on-going R\&D activities. Thus, we also controlled for Cash which was measured as the ratio of cash assets to total assets (Block, 2012; Gomez-Mejia et al., 2014). If firms performed better in the last year, they are more positive in engaging high-risk R\&D investments with sufficient resources. Therefore, we controlled for Prior performance which was measured by return on assets achieved (ROA) in the prior year (Chrisman \& Patel, 2012; Yu et al., 2019). We also accounted for board size, measured by the number of directors on the board (Campbell et al., 2019). Recent studies have shown that lone founder firms are more entrepreneurial and pursue superior R\&D investments (Block, 2012; 
Miller et al., 2011). We included a dummy Lone founder which equals 1 if the focal family firm is the lone founder firm and 0 otherwise. According to Miller, Le Breton-Miller, Lester, and Cannella Jr (2007) and Miller et al. (2011), lone founder firms are defined as firms which one of the firm's founder is active as an executive or major shareholder and no relatives of the founder are involved in the business as top managers or large shareholders. At the region level, we also controlled for Institutional development as there is a large institutional development disparities across regions in China which may influence firms' motivation to innovate and accessibility to local government's preferential policies and resources (Peng, 2003). We used regional marketization index from NERI which have been extensively used to measure institutional development in different regions in China (e.g., Kafouros, Wang, Piperopoulos, \& Zhang, 2015; Zhou, Gao, \& Zhao, 2017). Finally, we included two-digit industry dummies and year dummies to control for industry-related variance and time-dependent variations.

\section{Estimation method}

We employed feasible generalized least squares (GLS) estimation method with a first-order autoregressive $\mathrm{AR}(1)$ and heteroskedastic error structure to test our hypotheses (e.g., Cannella Jr, Park, \& Lee, 2008; Souder, Zaheer, Sapienza, \& Ranucci, 2017; Yang, Zheng, \& Zhao, 2014). We lagged all firm-level variables to alleviate the endogeneity problem of reverse causality.

As mentioned above, sample selection bias may be present among firms due to the missing value of birth order information (Heckman, 1979). We therefore adopted Heckman two-stage model to account for such potential nonrandom sampling bias. Our first-stage probit model predicted the presence of birth order information of the family owner. As shown in Panel B of the Table 1A, the coefficients on Rich list $(p<0.001)$ and Corporate donation $(p<0.05)$ is 
significant and positive, suggesting the validity of our instruments. We then included the predicted inverse Mill's ratio (IMR) from the first-stage regression in the second stage of the regressions.

\section{RESULTS}

\section{Descriptive Statistics}

Table 1 presents descriptive statistics of main variables and their correlations. The mean value of $R \& D$ intensity is $4 \%$, much lower than $10.40 \%$ reported in Block (2012) based on family firms in the S\&P 500, which clearly suggests that Chinese family firms are relatively reluctant to invest in risky R\&D projects. The mean value of birth order of owner is 1.5 and family owners are also CEOs in $36.0 \%$ of sample family firms. Only $16 \%$ of family firms are showing more than one generation are managing family firms together, which confirms that China's family firms are younger than western firms. Regarding the correlation matrix of main variables, the highest correlation is between Owner birth order and The number of siblings $(r=0.629, p<0.01)$. This is expected because a later birth order is possibly only to the extent that family size increases (Campbell et al., 2019). We calculated the average variance inflation factor (VIFs) for each model and the highest average VIF is 2.18 and the maximum value for any variables is 5.24 , less than the common cut-off point of 10 (Cohen, West, \& Aiken, 2003). Therefore, the problem of multicollinearity is not a major concern for this study.

\section{/Insert Table 1 about here/}

\section{Regression Results Analysis}

Table 2 presents the GLS regression results predicting R\&D intensity. Hypothesis 1 proposes that family owner as laterborns are more likely to engage in higher levels of $R \& D$ 
investments than earlier-borns. In Model 2 of Table 2, the coefficient on owner birth order is positive and significant $(\beta=0.0021, p=0.012)$, confirming that under later-born owners, $R \& D$ investment intensity will increase by an average of $5.25 \%(=0.0021 / 0.04)$ relative to the mean of $R \& D$ intensity. Therefore, Hypothesis 1 is well supported.

\section{/Insert Table 4 about here/}

Hypothesis 2 predicts that the presence of other family member as chairperson on board will negatively moderate the positive relationship between birth order and R\&D investments. The regression coefficient on the interaction term owner birth order $\times$ Family member chairperson is significantly negative in Model $3(\beta=-0.0065, p=0.000)$, suggesting that the presence of family member as the chairperson weakens the positive association between birth order and R\&D investment, supporting Hypothesis 2. In contrast, the interaction term owner birth order $\times$ Owner-CEO duality is positive and significant in Model $4(\beta=0.0092, p=0.000)$, which indicates that the presence of owner-CEO duality enhances the positive impact of birth order on R\&D investment, supporting Hypothesis 3. The full model in Model 5 shows similar results and provides consistent support for Hypotheses 2 and 3.

\section{/Insert Table 2 about here/}

To interpret our results in a visionary way, holding all other variables at their means, we calculated the adjusted predictions on the relationship between owner birth order and $R \& D$ investment. We used STATA Command 'margins' and 'marginsplot' to plot the estimates in Figure 1, 2 and 3 for Hypotheses 1, 2 and 3 respectively. Note that birth order in our sample is from 1 to 7. As Figure 1 shows, owner birth order is positively associated with R\&D investment intensity. In Figure 2, it plots the moderating effect of the presence of family member as the 
chairperson. As shown in Figure 2, when the chairperson position is taken by one of owner's family members, the positive relationship between owner birth order and R\&D investment intensity is weaker (see the flatter slope of the solid line than the dotted line in Figure 2), further supporting the negative moderating effect of family member chairperson in Hypothesis 2. As Figure 3 shows, owner birth order has a much stronger positive relationship with R\&D investments intensity when owner is also the CEO in the company (see the steeper slope of the solid line than the dotted line in Figure 3).

\section{/Insert Figures 1, 2 and 3 about here/}

\section{DISCUSSION}

Birth order, capturing individual's early life in the family domain, have substantial impact on R\&D investment decisions. Drawing on evolutionary psychology and family innovation literature, we find evidence that family owners who are later-borns are more actively investing in $\mathrm{R} \& \mathrm{D}$ projects. We also conjecture that such positive relationship is suppressed when there is a presence of family member as the chairperson on the board. In contrast, when there is a presence of owner-CEO duality in family firms, the positive birth order effects on R\&D investments is strengthened. Our theorizing and results make following primary contributions to the literature.

First, we introduce birth order as a pivotal but largely ignored micro factor to reconcile the debate on the paradox of family firms' innovation. Although prior studies have provided a wealth of insights to understand family innovation behaviors, dominate research has largely focused on how family ownership or family management (i.e., family influence) affect R\&D investments and have inconclusive findings (e.g., Chrisman \& Patel, 2012; De Massis et al., 2013; Duran et al., 2016; Gomez-Mejia et al., 2014; Gomez-Mejia et al., 2007). We argue that such 
implicitly treating family influence as a whole in previous studies will downplay the important individual differences, especially individual's early life experience, which actually account for large variances on family firms' R\&D investments. Built on evolutionary psychology (EP), we move beyond family influence as a whole and investigate the family owner's birth order, which captures risk-tolerances variances of decision-makers. We theorize birth order reflects how sibling compete in a family, and this in turn, shapes sibling's risk-taking tendencies in their adulthood. Specifically, we find that firstborn siblings are more conservative about R\&D investment, while later-born siblings are more likely to be active innovators. This is of great importance to provide a nascent explanation to prior mixed findings. At the same time, we also suggest future research on exploring micro-level/individual-level heterogeneities of major decision makers is much needed when studying innovation heterogeneities among family firms.

Second, our studies also respond to the emerging and persistent call for focusing studies on sources of heterogeneities across family firms rather than on differences between the "average" family firm and the "average" nonfamily firm, assuming family firms are homogenous groups rather than may vary in behaviors as much as or more than non-family firms (Chua et al., 2012). The homogenous assumption "produced results plagued by persistent inconsistencies and contradictions" (Chua et al., 2012: 1111), and in reality "does not exist, are often overgeneralized with limited explanatory power"(Chua et al., 2012). This issue is salient in family innovation literature where most studies have failed to consider the heterogeneities across family firms that may substantially contribute to divergent R\&D investment decisions (Chrisman \& Patel, 2012; De Massis et al., 2013). Aligned with few scholars who have emphasized family firm heterogeneities (Chrisman et al., 2015; Chrisman \& Patel, 2012; Duran et al., 2016), we suggest that birth orders of family owners and its interaction with family management factors (i.e., 
family member as chairperson and owner-CEO duality) cause substantial variabilities across family firms.

Third, by adding "family" life into family business research, we shift the conversation around business to integrate the family dynamics in understanding variances of R\&D investments in family business studies (Dyer, 2003; Jaskiewicz et al., 2017). Although it is well-accepted that family firms differ from non-family firms in that they simultaneously operate under business and familial principles (Chua et al., 1999; Gomez-Mejia et al., 2007), there is a dearth of research incorporating "family" side of the story. As noted, "If organizational scholars do not account for the family as a variable in their research, they will be incapable of accounting for the behavior of a significant population of organizations they purport to understand", (Dyer, 2003: 404). Given there are increasing attention on family elements, most of them still focus on family ties and goals values (Belenzon, Patacconi, \& Zarutskie, 2016; Dyer, 2003). In our study, our conceptualization of birth order effects extend family elements and shows a strong case to consider family member's early life experience in the family domain, where individual is raised and develop preferences and approaches to external environment (Sulloway, 2001). Specifically, follow one exception using EP theory to investigate CEO selection and executive compensation among family firms (Yu et al., 2019), our application of EP also shows a good fit to explain how family dynamics (i.e., birth order) shapes R\&D investment decisions. As noted by Nicholson (2008b:74), "The goal of EP theory and research is to identify and analyze the contents of our evolved human nature, understand how they are reflected in everyday social life and experience, and consider the implications for human well-being, effectiveness, and change". Overall, we believe our research responds to the recent call for leveraging family science theories (Jaskiewicz 
et al., 2017) and psychological perspective (Sharma et al., 2019) to understand family firms' behaviors.

Lastly, our findings advance the SEW perspective by validating SEW boundaries in family business studies. Although SEW is a "homegrown" lens for comparing the strategic decisions of family firms and non-family firms, the application of SEW is sensitive to contexts (Berrone et al., 2012; Minichilli et al., 2014; Naldi, Cennamo, Corbetta, \& Gomez-Mejia, 2013), such as family ownership (Calabrò et al., 2018; Souder et al., 2017), performance hazard (Chrisman \& Patel, 2012; Gomez-Mejia et al., 2014; Gomez-Mejia et al., 2007), CEO characteristics (Chen \& Hsu, 2009; Duran et al., 2016), and generations (Kraiczy et al., 2015; Schmid et al., 2014). Drawn on EP, our findings share the similar idea, but we further provide nascent evidence that SEW influences are individual-sensitive in having a stronger impact on earlier-born rather than on later-born family owners. That is, later-borns tend to be greater risk-takers with less SEW bounded. Thus, we add a new micro element to advance the SEW literature and explain why SEW guides some family firms more strongly than others (Berrone et al., 2012).

\section{LIMITATIONS AND FUTURE RESEARCH}

As with all research, our study suffers from several limitations, which offer opportunities for future research. First, due to data availability, we were not able to have enough information on siblings in the family firms. Future studies could extend our research and invetigate different sibling rivary contingencies such as sibling age gaps an the death of siblings. Second, birth order can be viewed as both biological and psychological (Shulman \& Mosak, 1977). That is, biological birth order changes when siblings are born or die, but psychological birth order most 
substantially influences individual personality. Our data restricted our test to biological birth order, while future research could deepen and expand our findings by considering psychological birth order. Second, risk to SEW may vary depending on whether R\&D investments are exploitative or exploratory (Patel \& Chrisman, 2014). We focused on overall R\&D investments, so our research could be expanded to observe how birth order influences on different types of R\&D investment, depending on available data. Finally, gender is a significant factor for considering the influence of birth order (Eckstein et al., 2010). However, as women are extremely underrepresented in our sample, we failed to explore the interaction effects between gender and birth order for R\&D investment. Future research might focus on other countries where top management positions feature high gender diversity. 


\section{REFERENCES}

Argys, L. M., Rees, D. I., Averett, S. L., \& Witoonchart, B. 2006. Birth order and risky adolescent behavior. Economic Inquiry, 44(2): 215-233.

Ashwin, A., Krishnan, R. T., \& George, R. 2015. Family firms in India: Family involvement, innovation and agency and stewardship behaviors. Asia Pacific Journal of Management, 32(4): 869-900.

Baliga, B. R., Moyer, R. C., \& Rao, R. S. 1996. CEO duality and firm performance: What's the fuss? Strategic Management Journal, 17(1): 41-53.

Barnes, L. B. 1988. Incongruent hierarchies: Daughters and younger sons as company CEOs. Family Business Review, 1(1): 9-21.

Beck, L., Janssens, W., Debruyne, M., \& Lommelen, T. 2011. A study of the relationships between generation, market orientation, and innovation in family firms. Family Business Review, 24(3): 252-272.

Belenzon, S., Patacconi, A., \& Zarutskie, R. 2016. Married to the firm? A large-scale investigation of the social context of ownership. Strategic Management Journal, 37(13): 2611-2638.

Berrone, P., Cruz, C., \& Gomez-Mejia, L. R. 2012. Socioemotional wealth in family firms: Theoretical dimensions, assessment approaches, and agenda for future research. Family Business Review, 25(3): 258-279.

Berrone, P., Cruz, C., Gomez-Mejia, L. R., \& Larraza-Kintana, M. 2010. Socioemotional wealth and corporate responses to institutional pressures: Do family-controlled firms pollute less? Administrative Science Quarterly, 55(1): 82-113.

Bertoni, M., \& Brunello, G. 2016. Later-borns don't give up: The temporary effects of birth order on European earnings. Demography, 53(2): 449-470.

Block, J. H. 2012. R\&D investments in family and founder firms: An agency perspective. Journal of Business Venturing, 27(2): 248-265.

Booth, A. L., \& Kee, H. J. 2009. Birth order matters: the effect of family size and birth order on educational attainment. Journal of Population Economics, 22(2): 367-397.

Calabrò, A., Minichilli, A., Amore, M. D., \& Brogi, M. 2018. The courage to choose! Primogeniture and leadership succession in family firms. Strategic Management Journal, 39(7): 2015-2035.

Campbell, R. J., Jeong, S.-H., \& Graffin, S. D. 2018. Born to Take Risk? The Effect of CEO Birth Order on Strategic Risk Taking. Academy of Management Journal.

Campbell, R. J., Jeong, S.-H., \& Graffin, S. D. 2019. Born to take risk? The effect of CEO birth order on strategic risk taking. Academy of Management Journal, 62(4): 1278-1306.

Cannella Jr, A. A., Park, J.-H., \& Lee, H.-U. 2008. Top management team functional background diversity and firm performance: Examining the roles of team member colocation and environmental uncertainty. Academy of Management Journal, 51(4): 768-784.

Chen, H.-L., \& Hsu, W.-T. 2009. Family ownership, board independence, and R\&D investment. Family Business Review, 22(4): 347-362.

Choi, Y. R., Zahra, S. A., Yoshikawa, T., \& Han, B. H. 2015. Family ownership and R\&D investment: The role of growth opportunities and business group membership. Journal of Business Research, 
68(5): 1053-1061.

Chrisman, J. J., Chua, J. H., De Massis, A., Frattini, F., \& Wright, M. 2015. The ability and willingness paradox in family firm innovation. Journal of Product Innovation Management, 32(3): 310-318.

Chrisman, J. J., \& Patel, P. C. 2012. Variations in R\&D investments of family and nonfamily firms: Behavioral agency and myopic loss aversion perspectives. Academy of Management Journal, 55(4): 976-997.

Chua, J. H., Chrisman, J. J., \& Sharma, P. 1999. Defining the family business by behavior. Entrepreneurship Theory and Practice, 23(4): 19-39.

Chua, J. H., Chrisman, J. J., Steier, L. P., \& Rau, S. B. 2012. Sources of Heterogeneity in Family Firms: An Introduction. Entrepreneurship Theory and Practice, 36(6): 1103-1113.

Cohen, P., West, S. G., \& Aiken, L. S. 2003. Applied multiple regression/correlation analysis for the behavioral sciences. Mahwah, NJ: Lawrence Erlbaum Associates.

Darwin, C. 1859. On the Origin of Species: Or the Preservation of Favoured Races in the Struggle for Life. London: John Murray

Darwin, C. 1968. On the origin of species by means of natural selection. London: Murray.

De Massis, A., Frattini, F., \& Lichtenthaler, U. 2013. Research on technological innovation in family firms: Present debates and future directions. Family Business Review, 26(1): 10-31.

De Massis, A., Kotlar, J., Chua, J. H., \& Chrisman, J. J. 2014. Ability and willingness as sufficiency conditions for family-oriented particularistic behavior: Implications for theory and empirical studies. Journal of Small Business Management, 52(2): 344-364.

Dunn, J., \& Plomin, R. 1990. Separate lives: Why siblings are so different. New York: Basic Books.

Duran, P., Kammerlander, N., Van Essen, M., \& Zellweger, T. 2016. Doing more with less: Innovation input and output in family firms. Academy of Management Journal, 59(4): 1224-1264.

Dyer, J. W. G. 2003. The family: The missing variable in organizational research. Entrepreneurship theory and practice, 27(4): 401-416.

Eckstein, D., Aycock, K. J., Sperber, M. A., McDonald, J., Van Wiesner III, V., Watts, R. E., \& Ginsburg, P. 2010. A Review of 200 Birth-Order Studies: Lifestyle Characteristics. Journal of Individual Psychology, 66(4).

Fan, G., Wang, X., \& Zhu, H. 2011. NERI index of marketization of China's provinces 2011 report. Economic Science Press, Beijing.

Gilliam, J., \& Chatterjee, S. 2011. The influence of birth order on financial risk tolerance. Journal of Business \& Economics Research (JBER), 9(4): 43-50.

Gomez-Mejia, L. R., Cruz, C., Berrone, P., \& De Castro, J. 2011. The bind that ties: Socioemotional wealth preservation in family firms. Academy of Management Annals, 5(1): 653-707.

Gomez-Mejia, L. R., Nunez-Nickel, M., \& Gutierrez, I. 2001. The role of family ties in agency contracts. Academy of Management Journal, 44(1): 81-95.

Gomez-Mejia, L. R., Campbell, J. T., Martin, G., Hoskisson, R. E., Makri, M., \& Sirmon, D. G. 2014. Socioemotional wealth as a mixed gamble: revisiting family firm R \& D investments with the behavioral agency model. Entrepreneurship Theory and Practice, 38(6): 1351-1374.

Gomez-Mejia, L. R., Haynes, K. T., Núñez-Nickel, M., Jacobson, K. J., \& Moyano-Fuentes, J. 2007. 
Socioemotional wealth and business risks in family-controlled firms: Evidence from Spanish olive oil mills. Administrative Science Quarterly, 52(1): 106-137.

Gomez-Mejia, L. R., Makri, M., \& Kintana, M. L. 2010. Diversification decisions in family-controlled firms. Journal of Management Studies, 47(2): 223-252.

Greve, H. R. 2003. A behavioral theory of R\&D expenditures and innovations: Evidence from shipbuilding. Academy of Management Journal, 46(6): 685-702.

Hamilton, W. D. 1964. The genetical evolution of social behaviour. Journal of Theoretical Biology, 7(7): $1-52$.

Healey, M. D., \& Ellis, B. J. 2007. Birth order, conscientiousness, and openness to experience: Tests of the family-niche model of personality using a within-family methodology. Evolution and Human Behavior, 28(1): 55-59.

Heckman, J. J. 1979. Sample selection bias as a specification error. Econometrica, 47(1): 153-161.

Hertwig, R., Davis, J. N., \& Sulloway, F. J. 2002. Parental investment: how an equity motive can produce inequality. Psychological bulletin, 128(5): 728.

Jaskiewicz, P., Combs, J. G., Shanine, K. K., \& Kacmar, K. M. 2017. Introducing the family: A review of family science with implications for management research. Academy of Management Annals, 11(1): 309-341.

Kafouros, M., Wang, C., Piperopoulos, P., \& Zhang, M. 2015. Academic collaborations and firm innovation performance in China: The role of region-specific institutions. Research Policy, 44(3): 803-817.

Kim, H., Kim, H., \& Lee, P. M. 2008. Ownership structure and the relationship between financial slack and R\&D investments: Evidence from Korean firms. Organization Science, 19(3): 404-418.

Kimhi, A. 1997. Intergenerational succession in small family businesses: Borrowing constraints and optimal timing of succession. Small Business Economics, 9(4): 309-318.

König, A., Kammerlander, N., \& Enders, A. 2013. The family innovator's dilemma: How family influence affects the adoption of discontinuous technologies by incumbent firms. Academy of Management Review, 38(3): 418-441.

Kraiczy, N. D., Hack, A., \& Kellermanns, F. W. 2014. New product portfolio performance in family firms. Journal of Business Research, 67(6): 1065-1073.

Kraiczy, N. D., Hack, A., \& Kellermanns, F. W. 2015. What makes a family firm innovative? CEO risk-taking propensity and the organizational context of family firms. Journal of Product Innovation Management, 32(3): 334-348.

La Porta, R., Lopez-de-Silanes, F., \& Shleifer, A. 1999. Corporate ownership around the world. The Journal of Finance, 54(2): 471-517.

Lee, P. M., \& O'neill, H. M. 2003. Ownership structures and R\&D investments of US and Japanese firms: Agency and stewardship perspectives. Academy of Management Journal, 46(2): 212-225.

Liu, Y., Chen, Y.-J., \& Wang, L. C. 2017. Family business, innovation and organizational slack in Taiwan. Asia Pacific Journal of Management, 34(1): 193-213.

Matzler, K., Veider, V., Hautz, J., \& Stadler, C. 2015. The impact of family ownership, management, and governance on innovation. Journal of Product Innovation Management, 32(3): 319-333. 
McDermott, C. M., \& O'Connor, G. C. 2002. Managing radical innovation: an overview of emergent strategy issues. Journal of Product Innovation Management, 19(6): 424-438.

Miller, D., Le Breton-Miller, I., Lester, R. H., \& Cannella Jr, A. A. 2007. Are family firms really superior performers? Journal of Corporate Finance, 13(5): 829-858.

Miller, D., Le Breton-Miller, I., \& Lester, R. H. 2011. Family and lone founder ownership and strategic behaviour: Social context, identity, and institutional logics. Journal of Management Studies, 48(1): 1-25.

Minichilli, A., Nordqvist, M., Corbetta, G., \& Amore, M. D. 2014. CEO succession mechanisms, organizational context, and performance: A socio-emotional wealth perspective on family-controlled firms. Journal of Management Studies, 51(7): 1153-1179.

Munari, F., Oriani, R., \& Sobrero, M. 2010. The effects of owner identity and external governance systems on R\&D investments: A study of Western European firms. Research Policy, 39(8): 1093-1104.

Muñoz-Bullón, F., \& Sanchez-Bueno, M. J. 2011. The impact of family involvement on the R\&D intensity of publicly traded firms. Family Business Review, 24(1): 62-70.

Naldi, L., Cennamo, C., Corbetta, G., \& Gomez-Mejia, L. 2013. Preserving socioemotional wealth in family firms: Asset or liability? The moderating role of business context. Entrepreneurship Theory and Practice, 37(6): 1341-1360.

Nicholson, N. 2008a. Evolutionary psychology and family business: A new synthesis for theory, research, and practice. Family Business Review, 21(1): 103-118.

Nicholson, N. 2008b. Evolutionary psychology, organizational culture, and the family firm. Academy of Management Perspectives, 22(2): 73-84.

Patel, P. C., \& Chrisman, J. J. 2014. Risk abatement as a strategy for R\&D investments in family firms. Strategic Management Journal, 35(4): 617-627.

Paulhus, D. L., Trapnell, P. D., \& Chen, D. 1999. Birth order effects on personality and achievement within families. Psychological Science, 10(6): 482-488.

Peng, M. W. 2003. Institutional transitions and strategic choices. Academy of Management Review, 28(2): 275-296.

Peng, M. W., \& Jiang, Y. 2010. Institutions behind family ownership and control in large firms. Journal of Management Studies, 47(2): 253-273.

Saad, G., Gill, T., \& Nataraajan, R. 2005. Are laterborns more innovative and nonconforming consumers than firstborns? A Darwinian perspective. Journal of Business Research, 58(7): 902-909.

Saroglou, V., \& Fiasse, L. 2003. Birth order, personality, and religion: A study among young adults from a three-sibling family. Personality and Individual differences, 35(1): 19-29.

Schenkel, M. T., Yoo, S. S., \& Kim, J. 2016. Not all created equal: examining the impact of birth order and role identity among descendant CEO sons on family firm performance. Family Business Review, 29(4): 380-400.

Schmid, T., Achleitner, A.-K., Ampenberger, M., \& Kaserer, C. 2014. Family firms and R\&D behavior-New evidence from a large-scale survey. Research Policy, 43(1): 233-244.

Schooler, C. 1972. Birth order effects: Not here, not now. Psychological Bulletin, 78(3): 161-175.

Schulze, W. S., Lubatkin, M. H., \& Dino, R. N. 2003. Toward a theory of agency and altruism in family 
firms. Journal of Business Venturing, 18(4): 473-490.

Sciascia, S., Nordqvist, M., Mazzola, P., \& De Massis, A. 2015. Family ownership and R\&D intensity in small-and medium-sized firms. Journal of Product Innovation Management, 32(3): 349-360.

Sharma, P., Chrisman, J. J., Chua, J. H., \& Steier, L. P. 2019. Family Firm Behavior From a Psychological Perspective. Entrepreneurship Theory and Practice: 1042258719879675.

Shulman, B. H., \& Mosak, H. H. 1977. Birth order and ordinal position: Two Adlerian views. Journal of Individual Psychology, 33(1): 114-121.

Sirmon, D. G., Arregle, J. L., Hitt, M. A., \& Webb, J. W. 2008. The role of family influence in firms' strategic responses to threat of imitation. Entrepreneurship Theory and Practice, 32(6): 979-998.

Smith, S. R., Hamon, R. R., Ingoldsby, B. B., \& Miller, J. E. 2012. Exploring Family Theories. New York: Oxford University Press

Souder, D., Zaheer, A., Sapienza, H., \& Ranucci, R. 2017. How family influence, socioemotional wealth, and competitive conditions shape new technology adoption. Strategic Management Journal, 38(9): 1774-1790.

Steelman, L. C. 1985. A tale of two variables: A review of the intellectual consequences of sibship size and birth order. Review of Educational Research, 55(3): 353-386.

Sulloway, F. J. 1994. Born to rebel: Radical thinking in science and social thought. Cambridge. MA: Massachusetts Institute of Technology

Sulloway, F. J. 1995. Birth order and evolutionary psychology: A meta-analytic overview. Psychological Inquiry, 6(1): 75-80.

Sulloway, F. J. 1996a. Born to rebel: birth order, family dynamics, and creative lives. New York: Pantheon Books.

Sulloway, F. J. 1996b. Born to rebel: Radical thinking in science and social thought. Cambridge. MA: Massachusetts Institute of Technology.

Sulloway, F. J. 1999. Birth order. In S. R. P. M. A. Runco (Ed.), Encyclopedia of creativity: 189-202. San Diego: Academic Press.

Sulloway, F. J. 2001. Birth order, sibling competition, and human behavior. Dordrecht, The Netherlands: Springer.

Sulloway, F. J., \& Zweigenhaft, R. L. 2010. Birth order and risk taking in athletics: A meta-analysis and study of major league baseball. Personality and Social Psychology Review, 14(4): 402-416.

Trivers, R. L. 1974. Parent-offspring conflict. Integrative and Comparative Biology, 14(1): 249-264.

Wiseman, R. M., \& Gomez-Mejia, L. R. 1998. A behavioral agency model of managerial risk taking. Academy of Management Review, 23(1): 133-153.

Yang, H., Zheng, Y., \& Zhao, X. 2014. Exploration or exploitation? Small firms' alliance strategies with large firms. Strategic Management Journal, 35(1): 146-157.

Yu, X., Stanley, L., Li, Y., Eddleston, K. A., \& Kellermanns, F. W. 2019. The Invisible Hand of Evolutionary Psychology: The Importance of Kinship in First-Generation Family Firms. Entrepreneurship Theory and Practice: 1042258719838256.

Zahra, S. A. 2005. Entrepreneurial risk taking in family firms. Family Business Review, 18(1): 23-40.

Zhou, K. Z., Gao, G. Y., \& Zhao, H. 2017. State ownership and firm innovation in China: An integrated 
view of institutional and efficiency logics. Administrative Science Quarterly, 62(2): 375-404.

Zweigenhaft, R. L., \& Von Ammon, J. 2000. Birth order and civil disobedience: A test of Sulloway's "born to rebel” hypothesis. The Journal of Social Psychology, 140(5): 624-627. 
TABLE 1

Descriptive Statistics and Correlations

\begin{tabular}{|c|c|c|c|c|c|c|c|c|c|c|}
\hline Variables & Mean & SD & 1 & 2 & 3 & 4 & 5 & 6 & 7 & 8 \\
\hline 1. R\&D investments intensity & 0.040 & 0.05 & 1 & & & & & & & \\
\hline 2. Owner birth order & 1.50 & 0.94 & -0 & 1 & & & & & & \\
\hline 3. Family member chairperson & 0.07 & 0.26 & -0.05 & 0.094 & 1 & & & & & \\
\hline 4. Owner-CEO duality & 0.36 & 0.48 & 0.232 & -0.01 & -0.194 & 1 & & & & \\
\hline 5. The number of siblings & 2.80 & 1.20 & -0.06 & 0.629 & 0.115 & -0.014 & 1 & & & \\
\hline 6. Family ownership & 0.41 & 0.14 & -0.01 & -0.118 & -0.03 & 0.15 & -0.073 & 1 & & \\
\hline 7. Generation & 0.16 & 0.37 & -0.13 & 0.087 & 0.105 & -0.119 & 0.043 & -0.124 & 1 & \\
\hline 8. Firm age & 11.00 & 4.80 & -0.08 & 0.024 & 0.156 & -0.082 & -0.054 & -0.241 & 0.169 & 1 \\
\hline 9. Firm size & 21.00 & 0.97 & -0.14 & 0.206 & 0.004 & -0.104 & 0.089 & 0.147 & 0.101 & 0.071 \\
\hline 10. Financial slack & 3.60 & 8.70 & 0.181 & 0.001 & 0.076 & 0.067 & -0.029 & -0.012 & 0.016 & 0.09 \\
\hline 11. Cash & 0.27 & 0.19 & 0.417 & -0.119 & -0.051 & 0.243 & -0.094 & 0.184 & -0.051 & -0.096 \\
\hline 12. Prior performance & 0.06 & 0.11 & -0.02 & -0.063 & 0.087 & -0.05 & -0.032 & 0.054 & 0.004 & -0.014 \\
\hline 13. Board size & 8.50 & 1.50 & -0.03 & 0.047 & 0.013 & -0.1 & 0.153 & -0.078 & 0.119 & 0.04 \\
\hline 14. Lone founder & 0.36 & 0.48 & -0.05 & 0.204 & -0.065 & -0.085 & 0.063 & -0.193 & 0.133 & 0.188 \\
\hline 15. Institutional environment & 7.60 & 1.40 & 0.133 & 0.039 & -0.011 & 0.136 & -0.047 & 0.095 & 0.002 & 0.018 \\
\hline \multirow[t]{2}{*}{ 16. Inverse Mills Ratio } & 1.30 & 0.22 & 0.204 & -0.097 & -0.042 & 0.143 & -0.121 & -0.306 & \multirow{2}{*}{$\begin{array}{ll} & 0.053 \\
16 & \\
\end{array}$} & 0.384 \\
\hline & 9 & 10 & \multicolumn{2}{|c|}{11} & 12 & 13 & 14 & 15 & & \\
\hline 9. Firm size & 1 & & & & & & & & & \\
\hline 10. Financial slack & -0.143 & 1 & & & & & & & & \\
\hline 11. Cash & -0.254 & 0.292 & 1 & & & & & & & \\
\hline 12. Prior performance & 0.056 & 0.003 & & 023 & 1 & & & & & \\
\hline 13. Board size & 0.235 & -0.02 & & & 0.023 & 1 & & & & \\
\hline 14. lone founder & 0.029 & -0.014 & & 132 & -0.038 & 0.059 & 1 & & & \\
\hline 15. Institutional environment & 0.058 & 0.022 & & 21 & -0.061 & -0.071 & -0.13 & 1 & & \\
\hline 16. Inverse Mills Ratio & -0.537 & 0.178 & & 15 & -0.108 & -0.155 & 0.116 & -0.084 & 1 & \\
\hline
\end{tabular}


Submission ID: 14330

TABLE 2

FGLS regression predicting R\&D investments

\begin{tabular}{|c|c|c|c|c|c|}
\hline & Model 1 & Model 2 & Model 3 & Model 4 & Model 5 \\
\hline \multirow[t]{2}{*}{ The number of siblings } & 0.0007 & 0.0001 & 0.0000 & -0.0009 & -0.0009 \\
\hline & $(0.0006)$ & $(0.0007)$ & $(0.0007)$ & $(0.0007)$ & $(0.0007)$ \\
\hline \multirow[t]{2}{*}{ Family ownership } & $0.0067 *$ & $0.0063 *$ & $0.0061 *$ & $0.0082 * *$ & $0.0086 * *$ \\
\hline & $(0.0038)$ & $(0.0037)$ & $(0.0037)$ & $(0.0036)$ & $(0.0036)$ \\
\hline \multirow[t]{2}{*}{ Generation } & $-0.0046 * * *$ & $-0.0053 * * *$ & $-0.0052 * * *$ & $-0.0041 * * *$ & $-0.0038 * * *$ \\
\hline & $(0.0013)$ & $(0.0013)$ & $(0.0013)$ & $(0.0013)$ & $(0.0013)$ \\
\hline \multirow[t]{2}{*}{ Firm age } & $-0.0013 * * *$ & $-0.0012 * * *$ & $-0.0013 * * *$ & $-0.0013 * * *$ & $-0.0014 * * *$ \\
\hline & $(0.0002)$ & $(0.0001)$ & $(0.0002)$ & $(0.0001)$ & $(0.0001)$ \\
\hline \multirow[t]{2}{*}{ Firm size } & 0.0007 & 0.0004 & 0.0007 & -0.0003 & -0.0002 \\
\hline & $(0.0008)$ & $(0.0008)$ & $(0.0008)$ & $(0.0007)$ & $(0.0007)$ \\
\hline \multirow[t]{2}{*}{ Financial slack } & 0.0000 & 0.0000 & 0.0000 & 0.0001 & 0.0000 \\
\hline & $(0.0001)$ & $(0.0001)$ & $(0.0001)$ & $(0.0001)$ & $(0.0001)$ \\
\hline \multirow[t]{2}{*}{ Cash } & $0.0140 * * *$ & $0.0179 * * *$ & $0.0167 * * *$ & $0.0197 * * *$ & $0.0175^{* * *}$ \\
\hline & $(0.0025)$ & $(0.0030)$ & $(0.0030)$ & $(0.0028)$ & $(0.0027)$ \\
\hline \multirow[t]{2}{*}{ Prior performance } & $0.0104 * * *$ & $0.0112 * * *$ & $0.0107 * * *$ & $0.0111 * * *$ & $0.0103 * * *$ \\
\hline & $(0.0033)$ & $(0.0036)$ & $(0.0035)$ & $(0.0037)$ & $(0.0035)$ \\
\hline \multirow[t]{2}{*}{ Board size } & $0.0005 *$ & 0.0005 & $0.0005 *$ & $0.0008 * * *$ & $0.0008 * * *$ \\
\hline & $(0.0003)$ & $(0.0003)$ & $(0.0003)$ & $(0.0003)$ & $(0.0003)$ \\
\hline \multirow[t]{2}{*}{ Lone founder } & 0.0013 & 0.0004 & 0.0007 & 0.0005 & 0.0007 \\
\hline & $(0.0012)$ & $(0.0012)$ & $(0.0012)$ & $(0.0011)$ & $(0.0011)$ \\
\hline \multirow[t]{2}{*}{ Institutional environment } & $0.0026^{* * *}$ & $0.0023 * * *$ & $0.0025 * * *$ & $0.0023 * * *$ & $0.0023 * * *$ \\
\hline & $(0.0004)$ & $(0.0004)$ & $(0.0004)$ & $(0.0003)$ & $(0.0003)$ \\
\hline \multirow[t]{2}{*}{ Inverse Mills Ratio } & $0.0301 * * *$ & $0.0267 * * *$ & $0.0282 * * *$ & $0.0291 * * *$ & $0.0301 * * *$ \\
\hline & $(0.0033)$ & $(0.0036)$ & $(0.0035)$ & $(0.0032)$ & $(0.0031)$ \\
\hline \multirow[t]{2}{*}{ Family members chairperson } & 0.0007 & 0.0024 & $0.0124 * * *$ & 0.0017 & $0.0096^{* *}$ \\
\hline & $(0.0025)$ & $(0.0025)$ & $(0.0040)$ & $(0.0024)$ & $(0.0039)$ \\
\hline \multirow[t]{2}{*}{ Owner-CEO duality } & $0.0018 *$ & $0.0024 * *$ & $0.0024 * *$ & $-0.0099 * * *$ & $-0.0083 * * *$ \\
\hline & $(0.0010)$ & $(0.0011)$ & $(0.0011)$ & $(0.0018)$ & $(0.0018)$ \\
\hline \multirow[t]{2}{*}{ Owner birth order } & & $0.0021 * *$ & $0.0029 * * *$ & 0.0001 & 0.0005 \\
\hline & & $(0.0008)$ & $(0.0009)$ & $(0.0009)$ & $(0.0009)$ \\
\hline \multirow{3}{*}{$\begin{array}{l}\text { Owner birth order*Family } \\
\text { member chairperson }\end{array}$} & & & & & \\
\hline & & & $-0.0065 * * *$ & & $-0.0044 * * *$ \\
\hline & & & (0.0016) & & $(0.0014)$ \\
\hline \multirow{3}{*}{$\begin{array}{l}\text { Owner birth } \\
\text { order*Owner-CEO duality }\end{array}$} & & & & & \\
\hline & & & & $0.0092 * * *$ & $0.0080 * * *$ \\
\hline & & & & $(0.0012)$ & $(0.0012)$ \\
\hline \multirow[t]{2}{*}{ Constant } & -0.0252 & 0.0253 & 0.0119 & 0.0351 & 0.0248 \\
\hline & $(0.0466)$ & $(0.0457)$ & $(0.0459)$ & $(0.0455)$ & $(0.0459)$ \\
\hline Observations & 747 & 747 & 747 & 747 & 747 \\
\hline The number of firms & 188 & 188 & 188 & 188 & 188 \\
\hline Chi-square & $1.3 \mathrm{e}+03 * * *$ & $1.1 \mathrm{e}+03^{* * *}$ & $1.2 \mathrm{e}+03 * * *$ & $2.9 \mathrm{e}+03 * * *$ & $2.5 \mathrm{e}+03 * * *$ \\
\hline
\end{tabular}

This table presents results using time-series feasible generalized least square (FGLS) model. Year and industry dummies are included in all specifications. Standard errors in parentheses. $* p<0.1 * * p<0.05 * * * p<0.01$. 


\section{FIGURE 1}

Adjusted predictions of birth order effect on R\&D investments (95\% confidence interval)

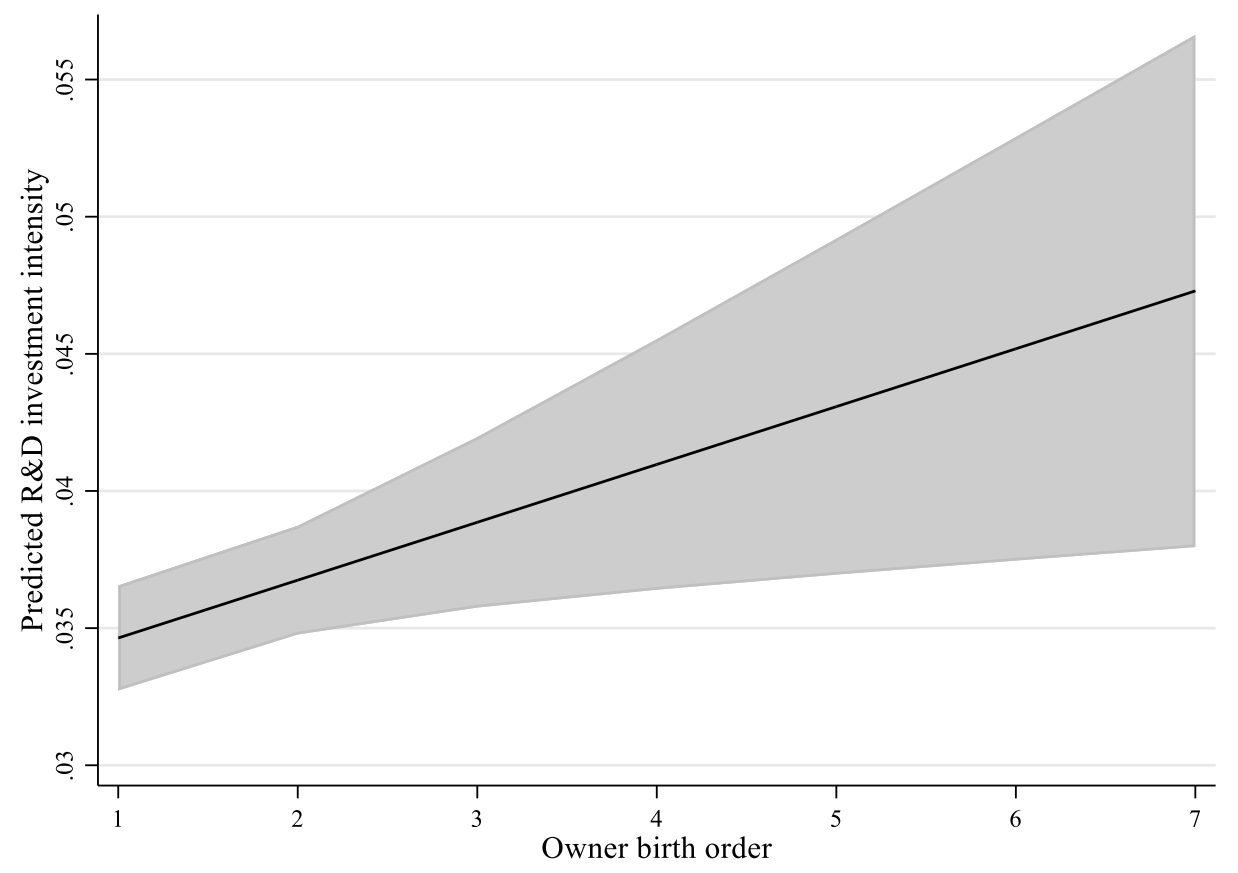

FIGURE 2

Moderating effect of family member chairperson 


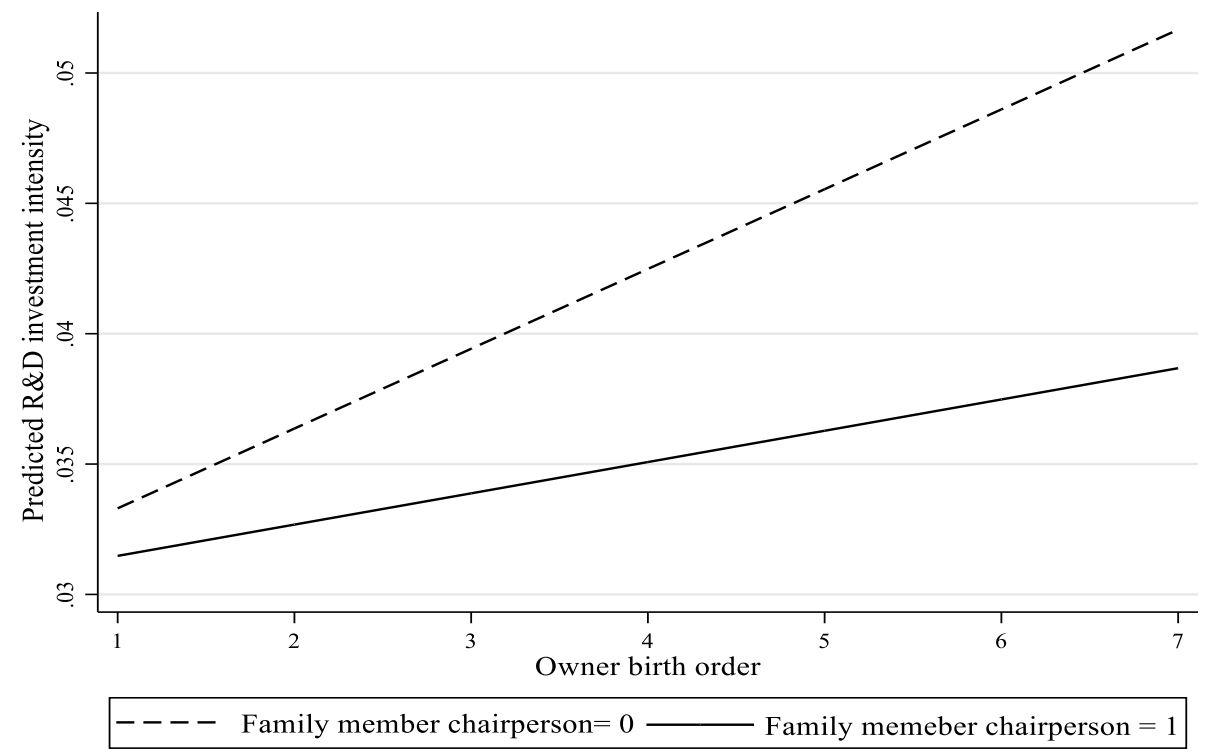

FIGURE 3

\section{Moderating effect of owner-CEO duality}

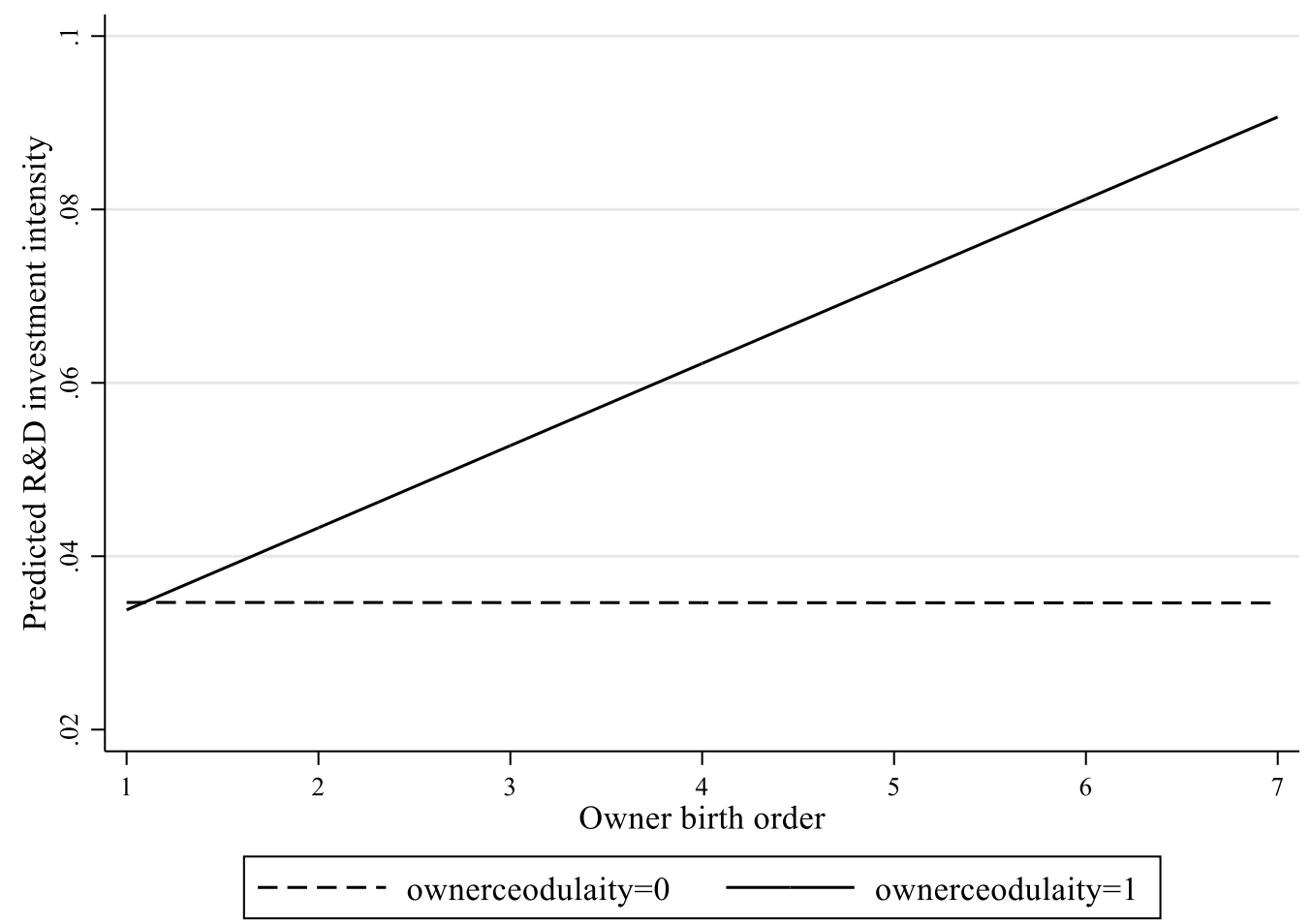




\section{APPENDIX TABLE A1}

\section{Heckman First stage regression results}

\section{Panel A: Descriptive statistics and correlations in the first stage}

\begin{tabular}{|c|c|c|c|c|c|c|c|c|c|}
\hline & Mean & SD & 1 & 2 & 3 & 4 & 5 & 6 & 7 \\
\hline 1. Firm size ${ }^{a}$ & 21.14 & 1.10 & 1 & & & & & & \\
\hline 2. Firm age & 11.99 & 5.41 & 0.0451 & 1 & & & & & \\
\hline 3. Financial slack & 3.42 & 6.49 & -0.091 & -0.0818 & 1 & & & & \\
\hline 4. Prior performance & 0.06 & 1.06 & 0.0322 & 0.0033 & 0.0075 & 1 & & & \\
\hline 5. Rich list & 0.47 & 0.50 & 0.3919 & 0.0772 & -0.0654 & -0.0097 & 1 & & \\
\hline 6. Corporate donation ${ }^{\mathrm{a}}$ & 8.06 & 6.06 & 0.4074 & -0.0514 & -0.0242 & 0.0125 & 0.1929 & 1 & \\
\hline 7. Institutional environment & 7.37 & 1.68 & 0.1337 & -0.0226 & 0.0654 & 0.0079 & 0.0341 & 0.0968 & 1 \\
\hline
\end{tabular}

Note: Correlations greater than $|0.023|$ are significant at $\mathrm{p}<.05$.

a Natural logarithm

\section{Panel B: Heckman first stage regression results}

\begin{tabular}{ll}
\hline & Model 1 \\
\hline Firm size & 0.0241 \\
& $(0.558)$ \\
Firm age & $-0.0187^{* *}$ \\
& $(0.018)$ \\
Financial slack & -0.0021 \\
& $(0.677)$ \\
Prior performance & 0.0019 \\
& $(0.813)$ \\
Rich list & $0.3748^{* * *}$ \\
& $(0.000)$ \\
Corporate donation & $0.0132^{* *}$ \\
& $(0.011)$ \\
Institutional environment & 0.0180 \\
& $(0.481)$ \\
Constant & -1.6602 \\
& $(0.109)$ \\
Observations & 9084 \\
Log Likelihood & $-4.3 \mathrm{e}+03$ \\
Wald Chi-square & $76.2827^{* * *}$ \\
\hline
\end{tabular}

Robust standard errors in parentheses. Year dummy and industry dummy are included.

$* p<0.1 * * p<0.05 * * * p<0.01$. 